\title{
PERANCANGAN TIANG PANCANG DENGAN TAHANAN FRIKSI NEGATIF
}

\author{
Vionita $^{1}$ dan Aksan Kawanda ${ }^{2}$ \\ ${ }^{1}$ Program Studi Sarjana Teknik Sipil, Universitas Tarumanagara, Jl. Letjen S. Parman No.1 Jakarta \\ vionita.325160066@stu.untar.ac.id \\ ${ }^{2}$ Program Studi Doktor Teknik Sipil, Universitas Katolik Parahyangan, Jl. Ciumbuleuit No.94, Jawa Barat \\ aksank@dtt.untar.ac.id
}

\begin{abstract}
Development in Jakarta took place the most, but the condition of the land in Jakarta which was dominated by soft soil was becoming an obstacle. Landfill is one way that can be done to strengthen or improve soft soil. But if this landfill causes a settlement in soil around the pile is bigger than the settlement in the pile, there will be negative skin friction which will cause the pile to be pulled down. This study aims to analyze and compare the magnitude of the influence of negative skin friction caused by the pile by using the undrained parameter, drained parameter, Meyerhof empirical, and Vesic empirical to analyze the carrying capacity of the pile and determine the neutral plane and negative skin friction with the Fellenius method and Prakash \& Sharma methods. From the results of the analysis,negative skin friction does not accur in the pile that ends hard soil while it occurs in soil that ends soft soil. The location of neutral plane between the Fellenius method and Prakash \& Sharma is not too different. But piles that experience negative skin friction need to be redesign. Changes in diameter of this pile can reach 2,5 times the initial size.
\end{abstract}

Keywords: negative skin friction; soft soil; Fellenius method; Prakash \& Sharma method

\begin{abstract}
ABSTRAK
Pembangunan di Jakarta sangat banyak, tetapi kondisi tanah di Jakarta yang didomisasi oleh tanah lunak menjadi kendala. Timbunan menjadi salah satu cara yang dapat dilakukan untuk memperkuat atau memperbaiki tanah lunak. Tetapi apabila timbunan ini menyebabkan penurunan tanah di sekitar tiang lebih besar daripada penurunan tiang maka akan timbul gesekan antara selimut tiang dengan tanah ke arah bawah yang akan menyebabkan tiang tertarik ke bawah. Gaya geser ke bawah ini dikenal sebagai gesekan selimut negatif. Studi ini bertujuan untuk menganalisis dan membandingkan besarnya pengaruh gesekan selimut negatif akibat timbunan dengan menggunakan metode undrained parameter, drained parameter, empiris Meyerhoff, dan empiris Vesic untuk menganalisis daya dukung tiang serta penentuan titik netral dan friksi negatif dengan metode Fellenius dan Prakash \& Sharma. Dari hasil analisis, gesekan selimut negatif tidak terjadi di tiang yang berujung tanah keras sedangkan terjadi di tanah pada tanah yang berujung tanah lunak. Letak tiitk netral antara metode Fellenius dan Prakash \& Sharma tidak terlalu berbeda. Tetapi tiang yang mengalami friksi negatif perlu didesain ulang ukurannya. Perubahan diameter tiang ini bisa mencapai 2,5 kali dari ukuran awal.
\end{abstract}

Kata kunci: gesekan selimut negatif; tanah lunak; metode Fellenius; metode Prakash \& Sharma

\section{PENDAHULUAN}

Tanah lunak merupakan tanah kohesif yang memiliki butiran yang sangat kecil seperti lempung atau lanau menurut Suyono Sosrodarsono dan Kazuto Nakazawa (2000). Sifat tanah lunak adalah kuat geser yang rendah dan kompresibilitas yang tinggi. Masalah yang dihadapi ketika pembangunan konstruksi dilakukan di atas tanah lunak adalah penurunan yang terjadi cenderung besar dan memakan waktu yang lama. Untuk mengatasi permasalahan ini, biasanya tanah lunak diperbaiki atau diperkuat. Salah satu cara yang digunakan yaitu dengan timbunan.

Timbunan yang cukup besar dapat menyebabkan fondasi tiang tertarik ke bawah. Hal ini dapat terjadi karena adanya gesekan antara selimut tiang dengan tanah di sekitar tiang karena penurunan tanah di sekitar tiang lebih besar dibandingkan penurunan tiang itu sendiri. Keadaan ini disebut juga dengan gesekan selimut negatif atau negative skin friction. Gesekan selimut negatif ini menyebabkan berkurangnya daya dukung ultimit tiang karena berkurangnya tegangan efektif pada ujung tiang. 
Gesekan selimut negatif biasa terjadi sampai dengan batas titik netral, yaitu titik dimana perbedaan antara penurunan tanah dengan peralihan tiang sama dengan nol sehingga tidak terjadi lagi gesekan antara selimut tiang dengan tanah. Pada bagian bawah dari titik netral ini akan ada tahanan ujung tiang atau biasa disebut juga tahanan selimut positif. Titik netral inilah yang menjadi titik yang menggambarkan kondisi setimbang antara friksi negatif yang berubah menjadi friksi positif.

\section{Studi parameter tanah}

Analisis parameter tanah dilakukan dengan cara membagi tanah sesuai dengan karakteristik tanah yang serupa. Penentuan parameter ini berdasarkan data tanah di lokasi konstruksi, data laboratorium, dan korelasi untuk data tanah lainnya yang diperlukan berdasarkan buku Binamarga (2019).

\section{Korelasi parameter tanah}

Kuat geser tak teralir ( $\mathrm{Su}$ atau $\mathrm{Cu}$ ) dapat diperoleh dari persamaan 1:

$$
\mathrm{Su}=6 \times \mathrm{N}-\mathrm{SPT}\left(\mathrm{kN} / \mathrm{m}^{3}\right)
$$

dengan N-SPT = jumlah pukulan yang dibutuhkan untuk penetrasi tabung belah standar.

Tegangan efektif dapat diperoleh dari persamaan 2:

$$
\sigma^{\prime}=\sigma-\mathrm{u}
$$

dengan $\sigma=$ tegangan total, $\mathrm{u}=$ tekanan air pori.

\section{Beban terbagi rata berbentuk trapesium memanjang tak terhingga}

Tambahan tegangan akibat beban timbunan $(\Delta \sigma)$ yang di buku Braja M. Das (2014) "Principle of Foundation Engineering" diagram tegangan tanah dapat diperoleh dari persamaan:

$$
\Delta \sigma=\frac{q o}{\pi}\left[\left(\frac{B 1+B 2}{B 2}\right)(\alpha 1+\alpha 2)-\frac{B 1}{B 2} \alpha 2\right]
$$

dengan qo = beban timbunan ( $\gamma$ timbunan $\mathrm{x} H$ timbunan), B1 = setengah lebar timbunan, $\mathrm{B} 2$ = panjang proyeksi horizontal kemiringan timbunan, $\alpha 1=\tan ^{-1}\left(\frac{B 1+B 2}{Z}\right)-\tan ^{-1}\left(\frac{B 1}{Z}\right), \alpha 2=\tan ^{-1}\left(\frac{B 1}{Z}\right), \mathrm{z}=$ kedalaman yang ditinjau.

\section{Penurunan tanah}

Penurunan tanah ketika tanah diberi beban atau penurunan seketika (St) dapat diperoleh dengan persamaan:

$$
S i=P \times B \times \frac{1-\mu^{2}}{E} \times I
$$

dengan $\mathrm{P}=$ beban terbagi rata, $\mathrm{B}=$ diameter fondasi, $\mathrm{Ip}=$ faktor pengaruh, $\mu=$ poisson rasio, $\mathrm{E}=$ modulus young. Penurunan tanah ketika tekanan air pori tanah disalurkan menuju partikel tanah atau penurunan konsolidasi (Sc) dapat diperoleh dari persamaan:

Untuk konsolidasi normal:

$$
S c=\frac{C c}{1+e o} H \log \left(\frac{\sigma^{\prime} z f}{\sigma^{\prime} z o}\right)
$$

dengan $\mathrm{Cc}=$ nilai kompresi indeks, eo = angka pori awal, $\mathrm{H}=$ tinggu tanah terkonsolidasi, $\sigma$ 'zf $=$ tegangan tanah akhir, $\sigma$ 'zo = tegangan tanah awal.

Untuk konsolidasi berlebih dengan $\sigma$ 'zf $\leq \sigma z o$ :

$$
S c=\frac{H}{1+e o} C s \log \left(\frac{\sigma^{\prime} z f}{\sigma^{\prime} z o}\right)
$$

dengan $\mathrm{Cs}=$ index pengembangan konsolidasi primer

Untuk konsolidasi berlebih dengan $\sigma$ 'zf $>\sigma c^{\prime}$ :

$$
S c=\left[\frac{H}{1+e o} C s \log \frac{\sigma c^{\prime}}{\sigma \prime z o}\right]\left[\frac{H}{1+e o} C c \log \frac{\sigma \prime z f}{\sigma c^{\prime}}\right]
$$

\section{Penurunan tiang}

Tiang pancang dapat mengalami penurunan apabila diberikan beban. Penurunan total tiang pancang (Se) dapat diperoleh dari persamaan: 


$$
S e=S e(1)+S e(2)+S e(3)
$$

dengan $\operatorname{Se}(1)=$ penurunan elastis tiang, $\operatorname{Se}(2)=$ penurunan tiang akibat beban ujung, $\operatorname{Se}(3)=$ penurunan tiang akibat beban disepanjang poros tiang.

Untuk penurunan elastis tiang dapat diperoleh dari persamaan:

$$
\mathbf{Q w p}=\frac{(Q w p+\xi Q w s) L}{A p E p}
$$

dengan $\mathrm{Qwp}=$ daya dukung ujung tiang, $\mathrm{Qws}=$ daya dukung selimut tiang, $\mathrm{Ap}=$ luas penampang ujung tiang, $\mathrm{L}=$ panjang tiang, $\mathrm{Ep}=$ modulus elastis material tiang, $\xi=0,5-0,67$.

Untuk penurunan tiang akibat beban ujung dapat diperoleh dengan persamaan:

$$
\operatorname{Se}(2)=\frac{q w p D}{E s}\left(1-\mu s^{2}\right) I w p
$$

dengan $\mathrm{D}=$ diameter tiang, $q w p=$ beban titik per luas, $\mathrm{Es}=$ modulus elastisitas tanah, Iwp = faktor pengaruh $=$ 0,85 .

Untuk penurunan tiang akibat beban disepanjang poros tiang dapat diperoleh dengan persamaan:

$$
\operatorname{Se}(3)=\frac{Q w s}{P L} \frac{D}{E s}\left(1-\mu s^{2}\right) I w s
$$

dengan $\mathrm{p}=$ keliling tiang, $\mathrm{L}=$ panjang tiang tertanam, Iws $=$ faktor pengaruh $=2+0,35 \sqrt{\frac{L}{D}}$.

\section{Kapasitas aksial tiang metode undrained parameter}

Daya dukung ultimit ujung tiang (Qult) pada tanah kohesif dimana parameter tanah $\phi=0$ Kemudian kohesi $\mathrm{c}=\mathrm{cu}$ $=$ Su dan faktor daya dukung $\mathrm{N}_{\gamma}=0$ dan $\mathrm{Nq}=1$ dapat diperoleh dengan persamaan:

$$
\text { Qult }=Q p+Q s=A p \times C u \times N c+p \times \sum \alpha \times C u \times \Delta L
$$

dengan $\mathrm{Qp}=$ daya dukung ultimit ujung tiang, $\mathrm{Qs}=$ daya dukung selimut tiang, Ap = luas penampang ujung tiang, $\mathrm{Cu}=$ kohesi tidak terdrainase, $\mathrm{Nc}=$ faktor daya dukung ujung, $\mathrm{p}=$ keliling tiang, $\mathrm{a}=$ faktor adesi, $\Delta \mathrm{L}=$ panjang segmen tiang.

\section{Kapasitas aksial tiang metode drained parameter}

Daya dukung ultimit ujung tiang (Qult) saat kondisi tanah drained dapat diperoleh dengan persamaan:

$$
Q u l t=Q p+Q s=A p x \sigma v^{\prime} x N q+p x \sum \Delta L x \sigma v^{\prime} x K s \tan \phi_{\text {a }}
$$

dengan $\mathrm{Qp}=$ daya dukung ultimit ujung tiang, $\mathrm{Qs}=$ daya dukung selimut tiang, $\mathrm{Ap}=$ luas penampang ujung tiang, $\sigma \mathrm{v}^{\prime}=$ tegangan vertikal efektif tanah, $\mathrm{Nq}=$ faktor daya dukng ujung, $\mathrm{p}=$ keliling tiang, $\Delta \mathrm{L}=$ panjang segmen tiang, $\mathrm{Ks}=$ konstanta, $\phi_{\mathrm{a}}=$ sudut geser dalam.

\section{Kapasitas aksial tiang metode Meyerhof (1956)}

Kapasitas daya dukung ultimit (Qult) dihitung berdasarkan nilai Nspt dari hasil pengujian lapangan yang dapat diperoleh dengan persamaan:

$$
\text { Qult }=40 \times N b \times A p+0.2 \times N s \times A s
$$

dengan $\mathrm{Nb}=$ harga $\mathrm{Nspt}$ pada dasar elevasi tiang, $\mathrm{Ap}=$ luas penampang tiang, $\mathrm{Ns}=$ nilai Nspt rata-rata sepanjang tiang, As = luas selimut tiang.

\section{Kapasitas aksial tiang metode Meyerhof (1976)}

Daya dukung ultimit ujung tiang $(\mathrm{Qp})$ untuk tiang di tanah jenuh dengan kondisi undrained $(\phi=0)$ dapat diperoleh dengan persamaan:

$$
Q p=N c x C u \times A p=9 \times C u \times A p
$$

dengan $\mathrm{Cu}=$ kohesi tak teralir, $\mathrm{Ap}=$ luas penampang tiang.

\section{Kapasitas aksial metode Vesic}

Daya dukung ultimit ujung tiang $(\mathrm{Qp})$ berdasarkan parameter tegangan efektif dapat diperoleh dengan persamaan: 


$$
Q p=A p \times q p=A p \times C u \times N c^{*}
$$

\section{Gesekan selimut negatif}

Menurut buku "Geotechnical Engineering Calculations and Rules of Thumb" (Rajapakse, 2016), gesekan selimut negatif adalah gaya hambat ke bawah yang diberikan oleh tumpukan tanah di sekitarnya. Sehingga dapat menyebabkan menurunnya kapasitas tiang. Akibatnya tanah akan mengalami penuranan sehingga tekanan air pori meningkat. Hal ini menyebabkan tiang tertarik ke bawah sehingga menimbulkan gesekan antara tanah dengan selimut tiang.

Selain gesekan selimut negatif, terdapat pula gesekan selimut positif yaitu ketika gaya gesekan negatif sudah tidak terjadi sehingga terjadi gaya tarik ke atas. Titik pertemuan antara perubahan ini disebut titik netral. Hal ini dapat dilihat pada Gambar 1. dimana terlihat perbedaan perubahan penurunan tanah dan peralihan tiang relatif sama dengan nol dan untuk mengetahui titik netral, dapat menggunakan kurva transfer beban yaitu Qu-Qs terhadap kedalaman dan Qd + Qn terhadap kedalaman.

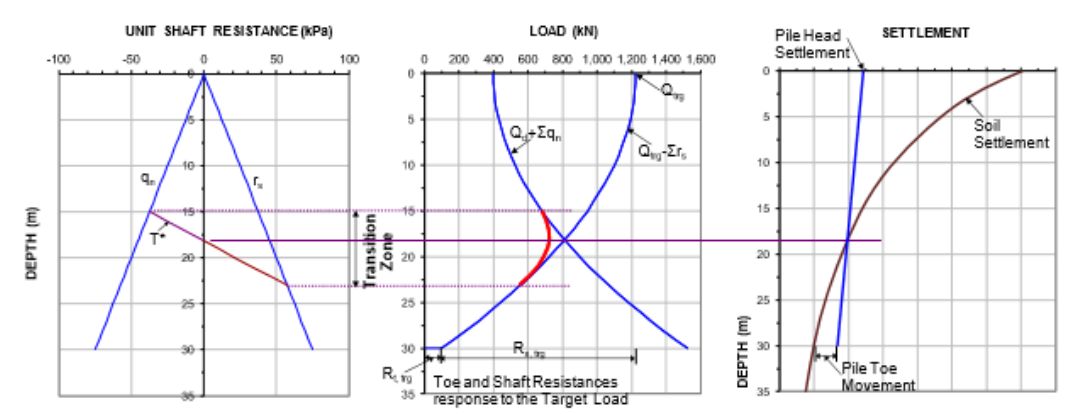

Gambar 1. Transisi dari gesekan selimut negatif ke gesekan selimut positif dan titik netral (Fellenius, 2020)

Selain metode Fellenius, terdapat juga metode Prakash \& Sharma yang menyatakan letak titik netral dapat diperoleh dengan persamaan:

$$
\text { Titik Netral }=0,75 \times H
$$

dimana $\mathrm{H}=$ panjang segmen tiang.

\section{Friksi negatif metode Fellenius}

Menghitung beban aksial total akibat gesekan friksi negatif $(\mathrm{Qz})$ menurut Fellenius dapat diperoleh dengan persamaan:

$$
Q z=Q d+\int A s q n d z=Q d+\int A s \beta \sigma^{\prime} z d z
$$

dengan $\mathrm{Qd}=$ beban aksial tiang, $\mathrm{Qn}=$ gaya tarik ke bawah di titik netral, As = luas selimut tiang, $\mathrm{qn}=$ unit friksi negatif, $\beta=$ koefisien, $\sigma ' z=$ tegangan efektif tanah.

Nilai koefisen beta dapat dilihat pada Tabel 1.

Tabel 1. Koefisien beta

\begin{tabular}{ccc}
\hline Soil & Phi & Beta \\
\hline Clay & $25-30$ & $0,15-0,35$ \\
Silt & $28-34$ & $0,25-0,50$ \\
Sand & $32-40$ & $0,30-0,90$ \\
Gravel & $35-45$ & $0,35-0,80$ \\
\hline \multicolumn{2}{l}{ Sumber: Fellenius, 2020) }
\end{tabular}

\section{Friksi negatif metode Prakash \& Sharma}

Untuk menghitung beban aksial total akibat friksi negatif (Fnegatif) pada tanah lunak menurut Prakash \& Sharma (1990) dapat diperoleh dengan persamaan:

$$
\text { Fnegatif }=p \sum_{L=0}^{L=L o} C u \Delta L
$$


dengan $\mathrm{p}=$ keliling tiang, $\mathrm{Cu}=$ kuat geser tanah, $\Delta \mathrm{L}=$ panjang segmen tiang.

\section{Daya dukung izin}

Tiang pancang yang berpotensi akan mengalami gesekan selimut negatif, daya dukung izinnya (Qizin) berdasarkan SNI 2847: 2013 dapat diperoleh dengan persamaan:

$$
\begin{aligned}
& \text { Qijin }=\frac{\text { Qultimit }-N S F}{3} \\
& \text { Qijin }=\frac{\text { Qultimit }}{2,5}-N S F
\end{aligned}
$$

Dari kedua persamaan tersebut, dipilih hasil yang terkecil yang pada akhirnya akan digunakan sebagai kapasitas izin tiang pancang.

\section{METODE PENELITIAN}

Seluruh langkah kerja yang dilakukan dalam penelitian ini dapat dilihat melalui kerangka berpikir yang terdapat pada Gambar 2.

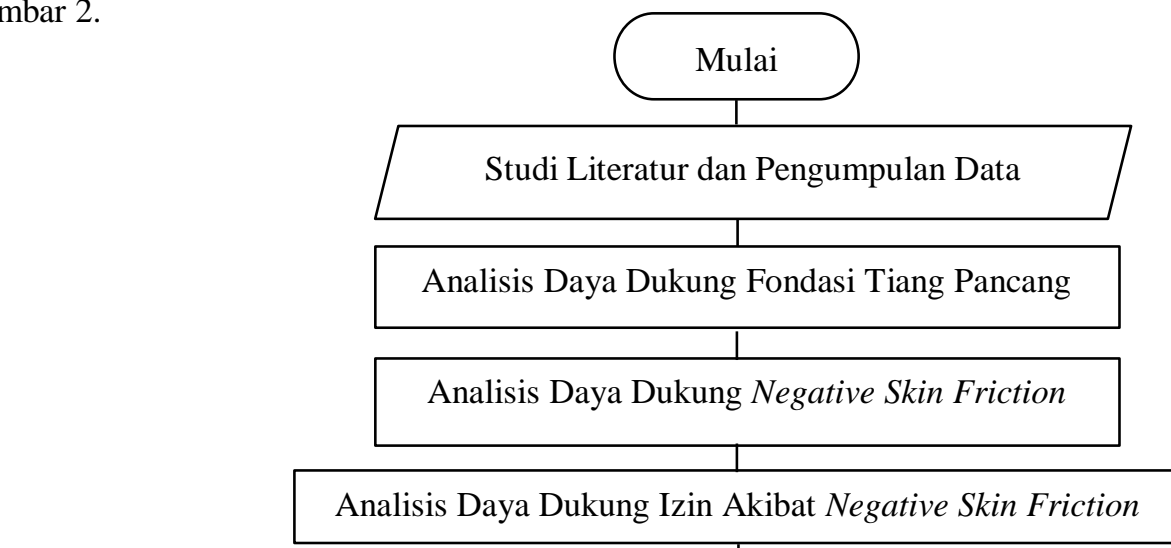

Membandingkan Daya Dukung Tiang dan Daya Dukung Izin Akibat Negative Skin Friction

Kesimpulan dan Saran

Selesai

Gambar 2. Diagram alir penelitian

\section{HASIL DAN PEMBAHASAN}

Data parameter tanah dari hasil uji tanah di lapangan, uji laboratorium, serta hasil korelasi potongan A-A dan B-B, dapat dilihat pada Tabel 2., untuk potongan C-C pada Tabel 3., dan potongan D-D pada Tabel 4. 
Tabel 2. Summary data parameter tanah potongan A-A dan B-B

\begin{tabular}{cccccccc}
\hline Kedalaman $(\mathrm{m})$ & $0-12$ & $12-14$ & $14-18$ & $18-24$ & $24-36$ & $36-40$ & $40-41$ \\
\hline $\mathrm{NSPT}$ & 2 & 8 & 44 & 11 & 17 & 25 & - \\
$\gamma$ sat $\left(\right.$ ton $\left./ \mathrm{m}^{2}\right)$ & 1,24 & 1,18 & 1,48 & 1,34 & 1,11 & 1,2 & 1,31 \\
$\gamma d r y\left(\operatorname{ton} / \mathrm{m}^{2}\right)$ & 0,79 & 0,86 & 1,21 & 0,9 & 1,06 & 1,17 & 1,25 \\
$\mathrm{Gs}$ & 2,52 & 2,56 & 2,63 & 2,57 & 2,62 & 2,63 & 2,64 \\
$\mathrm{e}$ & 2,46 & 2,21 & 1,6 & 2,05 & 1,46 & 1,24 & 1,31 \\
$\sigma$ '(ton $\left./ \mathrm{m}^{2}\right)$ & 13,15 & 19,72 & 21,72 & 25,93 & 36,49 & 45,76 & 46,42 \\
$\mathrm{u}\left(\mathrm{ton} / \mathrm{m}^{2}\right)$ & 9,95 & 15,02 & 15,02 & 20,34 & 31,39 & 39,24 & 39,73 \\
$\sigma\left(\mathrm{ton} / \mathrm{m}^{2}\right)$ & 3,21 & 4,7 & 4,7 & 5,58 & 5,59 & 6,52 & 6,68 \\
$\mathrm{Po}\left(\mathrm{kg} / \mathrm{cm}^{2}\right)$ & 0,24 & 0,44 & 0,45 & 0,56 & 0,56 & 0,65 & 0,67 \\
$\mathrm{Pc}\left(\mathrm{kg} / \mathrm{cm}^{2}\right)$ & 0,65 & 1,47 & 0,95 & 2,59 & 3,65 & 4,58 & 4,64 \\
$\mathrm{Cc}$ & 0,91 & 0,8 & 0,58 & 0,72 & 0,49 & 0,4 & 0,42 \\
$\mathrm{Cr}$ & 0,09 & 0,07 & 0,06 & 0,07 & 0,05 & 0,04 & 0,04 \\
$\mathrm{Cu}\left(\mathrm{kN} / \mathrm{m}^{2}\right)$ & 15 & 46,8 & 264 & 66 & 100 & 150 & - \\
& & & & & & & \\
\hline
\end{tabular}

Tabel 3. Summary data parameter tanah potongan C-C

\begin{tabular}{|c|c|c|c|c|c|c|c|c|c|c|c|c|c|}
\hline $\begin{array}{l}\text { Kedalaman } \\
(\mathrm{m})\end{array}$ & $0-10$ & $10-18$ & $18-22$ & $22-26$ & $26-30$ & $30-34$ & $34-38$ & $38-42$ & $42-46$ & $46-50$ & $50-54$ & $54-58$ & $58-60$ \\
\hline NSPT & 1 & 21 & 14 & 27 & 18 & 12 & 11 & 15 & 15 & 15 & 16 & 18 & 22 \\
\hline$\gamma s a t\left(\right.$ ton $\left./ \mathrm{m}^{2}\right)$ & 1,08 & 1,08 & 1,08 & 1,16 & 1,16 & 1,17 & 1,27 & 1,22 & 1,24 & 1,24 & 1,38 & 1,46 & 1,48 \\
\hline$\gamma d r y\left(\right.$ ton $\left./ \mathrm{m}^{2}\right)$ & 0,76 & 0,84 & 1,04 & 0,87 & 0,87 & 1,13 & 1,22 & 1,17 & 1,19 & 1,21 & 1,34 & 1,39 & 1,35 \\
\hline Gs & 2,64 & 2,59 & 2,61 & 2,60 & 2,6 & 2,62 & 2,63 & 2,63 & 2,63 & 2,63 & 2,64 & 2,65 & 2,64 \\
\hline $\mathrm{e}$ & 2,63 & 2,1 & 1,53 & 1,98 & 1,98 & 1,32 & 1,17 & 1,24 & 1,21 & 1,17 & 0,97 & 0,9 & 0,96 \\
\hline$\sigma^{\prime}\left(\right.$ ton $\left./ \mathrm{m}^{2}\right)$ & 8,82 & 17,42 & 23,11 & 30,3 & 34,94 & 39,62 & 44,7 & 49,58 & 54,54 & 59,5 & 65,02 & 70,86 & 74,49 \\
\hline $\mathrm{u}\left(\operatorname{ton} / \mathrm{m}^{2}\right)$ & 6,82 & 14,67 & 19,79 & 23,94 & 27,86 & 31,78 & 35,71 & 39,63 & 43,56 & 47,48 & 51,4 & 55,33 & 57,73 \\
\hline$\sigma\left(\operatorname{ton} / \mathrm{m}^{2}\right)$ & 2,01 & 2,76 & 3,32 & 6,37 & 7,08 & 7,84 & 9 & 9,95 & 10,99 & 12,02 & 13,62 & 15,54 & 16,76 \\
\hline $\operatorname{Po}\left(\mathrm{kg} / \mathrm{cm}^{2}\right)$ & 0,23 & 0,28 & 0,33 & 0,64 & 0,71 & 0,78 & 0,9 & 1 & 1,1 & 1,2 & 1,36 & 1,55 & 1,68 \\
\hline $\mathrm{Pc}\left(\mathrm{kg} / \mathrm{cm}^{2}\right)$ & 0,63 & 1,74 & 2,31 & 3,03 & 3,49 & 3,96 & 4,47 & 4,96 & 5,45 & 5,95 & 6,5 & 7,09 & 7,45 \\
\hline $\mathrm{Cc}$ & 0,98 & 0,74 & 0,51 & 0,69 & 0,69 & 0,43 & 0,37 & 0,4 & 0,38 & 0,37 & 0,29 & 0,26 & 0,28 \\
\hline $\mathrm{Cr}$ & 0,1 & 0,07 & 0,05 & 0,07 & 0,07 & 0,04 & 0,04 & 0,04 & 0,04 & 0,04 & 0,03 & 0,03 & 0,03 \\
\hline $\mathrm{Cu}\left(\mathrm{kN} / \mathrm{m}^{2}\right)$ & 8,3 & 126 & 84 & 162 & 108 & 72 & 66 & 90 & 90 & 90 & 96 & 108 & 132 \\
\hline
\end{tabular}

Tabel 4. Summary data parameter tanah potongan D-D

\begin{tabular}{ccccccccccc}
\hline Kedalaman $(\mathrm{m})$ & $0-8$ & $8-12$ & $12-20$ & $20-28$ & $28-32$ & $32-36$ & $36-44$ & $44-52$ & $52-56$ & $56-61$ \\
\hline $\mathrm{NSPT}$ & 5 & 13 & 17 & 12 & 19 & 19 & 12 & 17 & 10 & 12 \\
$\gamma$ sat $\left(\right.$ ton $\left./ \mathrm{m}^{2}\right)$ & 1,17 & 1,08 & 1,36 & 1,14 & 1,33 & 1,14 & 1,12 & 1,29 & 1,43 & 1,33 \\
$\gamma d r y\left(\right.$ ton $\left./ \mathrm{m}^{2}\right)$ & 0,91 & 0,79 & 1,2 & 1,09 & 1,32 & 1,09 & 1,10 & 1,22 & 1,38 & 1,06 \\
$\mathrm{Gs}$ & 2,6 & 2,59 & 2,63 & 2,62 & 2,64 & 2,62 & 2,62 & 2,63 & 2,65 & 2,62 \\
$\mathrm{e}$ & 216 & 2,37 & 1,36 & 1,42 & 1,01 & 1,41 & 1,39 & 1,21 & 0,93 & 1,59 \\
$\sigma$ (ton $\left./ \mathrm{m}^{2}\right)$ & 10,37 & 15,06 & 22,6 & 30,83 & 38,31 & 42,87 & 49,49 & 59,11 & 67,79 & 73,44 \\
$\mathrm{u}\left(\mathrm{ton} / \mathrm{m}^{2}\right)$ & 7,73 & 11,9 & 17,77 & 25,02 & 30,9 & 34,83 & 40,71 & 48,56 & 54,45 & 58,61 \\
$\sigma\left(\mathrm{ton} / \mathrm{m}^{2}\right)$ & 2,64 & 3,15 & 4,83 & 5,81 & 7,4 & 8,04 & 8,77 & 10,55 & 13,34 & 14,82 \\
$\mathrm{Po}\left(\mathrm{kg} / \mathrm{cm}^{2}\right)$ & 0,29 & 0,3 & 0,48 & 0,58 & 0,74 & 0,8 & 0,88 & 1,05 & 1,33 & 1,48 \\
$\mathrm{Pc}\left(\mathrm{kg} / \mathrm{cm}^{2}\right)$ & 0,93 & 1,15 & 2,26 & 3,08 & 3,83 & 4,29 & 4,95 & 5,91 & 6,78 & 7,34 \\
$\mathrm{Cc}$ & 0,74 & 0,82 & 0,44 & 0,47 & 0,3 & 0,46 & 0,46 & 0,38 & 0,27 & 0,54 \\
$\mathrm{Cr}$ & 0,08 & 0,08 & 0,04 & 0,05 & 0,03 & 0,05 & 0,05 & 0,04 & 0,03 & 0,05 \\
$\mathrm{Cu}\left(\mathrm{kN} / \mathrm{m}^{2}\right)$ & 31,3 & 78 & 102 & 69 & 114 & 114 & 69 & 102 & 60 & 72 \\
\hline
\end{tabular}

Ukuran tiang pancang yang digunakan berdasarkan parameter tanah dan kondisi beban 300 ton, safety factor 3, dan allowable 100 ton dapat dilihat pada Tabel 5. 
Tabel 5. Ukuran tiang pancang

\begin{tabular}{ccc}
\hline & $\begin{array}{c}\text { Panjang } \\
(\mathrm{m})\end{array}$ & $\begin{array}{c}\text { Diameter } \\
(\mathrm{mm})\end{array}$ \\
\hline Potongan A-A dan B-B & 16 & 500 \\
Potongan C-C & 21 & 300 \\
Potongan D-D & 30 & 200 \\
\hline
\end{tabular}

Dengan menggunakan panjang dan ukuran tiang pada Tabel 5., diperhitungkan daya dukung ultimit dan izin dengan menggunakan berbagai metode seperti yang dapat dilihat pada Tabel 6 .

Tabel 6. Perbandingan daya dukung berbagai metode (ton)

\begin{tabular}{cccccc}
\hline & Undrained & Drained & $\begin{array}{c}\text { Meyerhof } \\
(1956)\end{array}$ & $\begin{array}{c}\text { Meyerhof } \\
(1976)\end{array}$ & Vesic \\
\hline Qult potongan A-A dan B-B & 567,97 & 358,25 & 436,11 & 408,79 & 382,82 \\
Qizin potongan A-A dan B-B & 179,72 & 109,82 & 135,77 & 126,67 & 118,01 \\
Qult potongan C-C & 579,22 & 862,04 & 138,86 & 355,56 & 344,65 \\
Qizin potongan C-C & 175,31 & 269,58 & 2,25 & 88,93 & 84,56 \\
Qult potongan D-D & 360,31 & 669,97 & 73,35 & 402,07 & 397,04 \\
Qizin potongan D-D & 74,18 & 198,04 & $-40,61$ & 90,88 & 88,86 \\
\hline
\end{tabular}

Setelah perhitungan daya dukung tiang, selanjutkan kita menentukan titik netral tiang. Penentuan titik netral metode Fellenius pada potongan A-A dan B-B dapat dilihat pada Gambar 3., untuk potongan C-C pada Gambar 4. dan untuk potongan D-D pada Gambar 5.

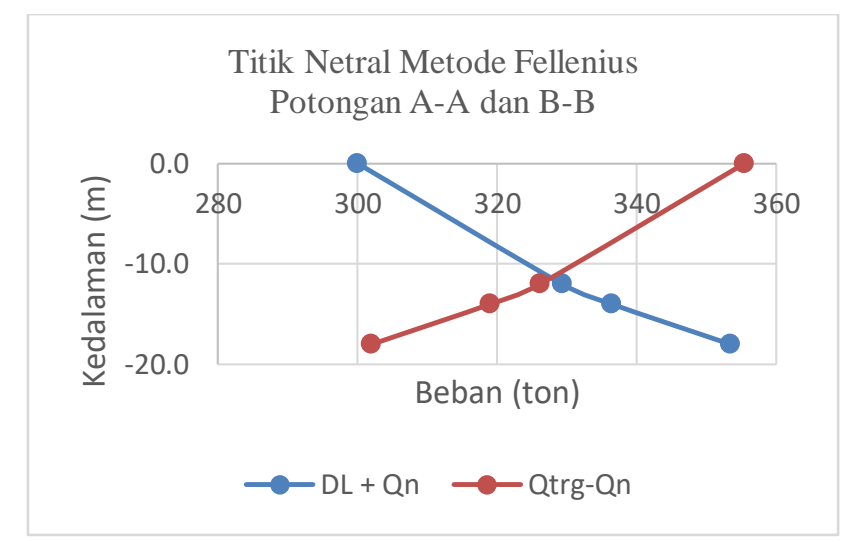

Gambar 3. Titik netral metode Fellenius potongan A-A dan B-B

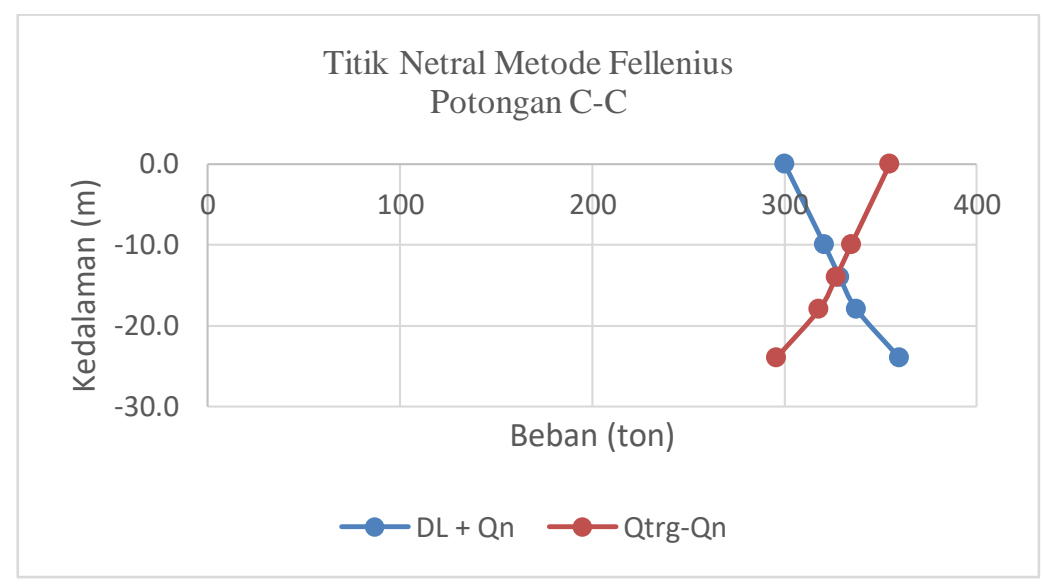

Gambar 4. Titik netral metode Fellenius potongan C-C 


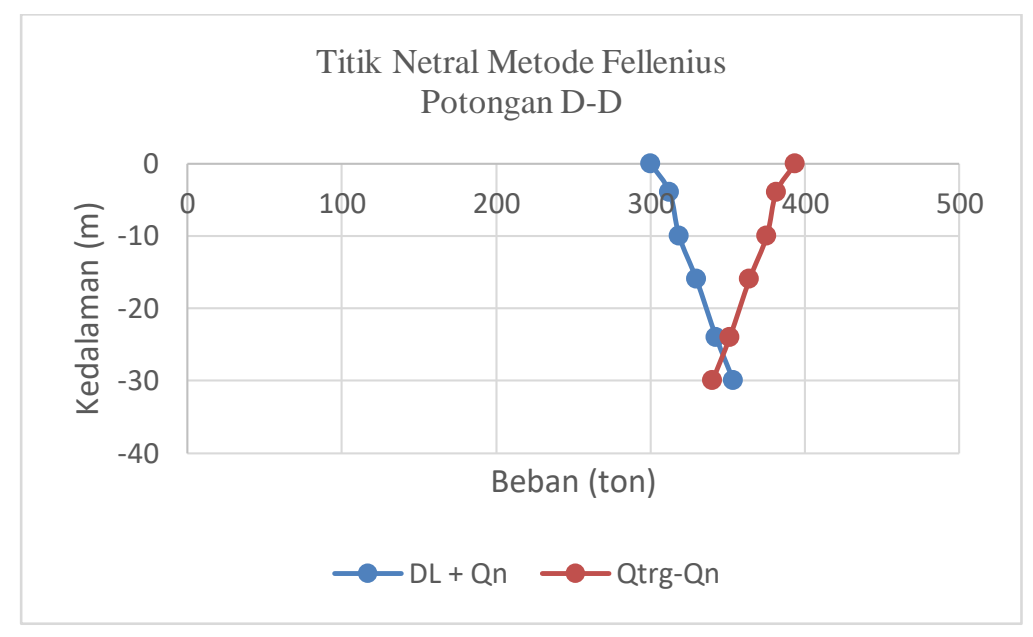

Gambar 5. Titik netral metode Fellenius potongan D-D

Nilai titik netral metode Prakash \& Sharma serta perbandingan titik netral serta besarnya friksi negatif untuk metode Fellenius dan Prakash \& Sharma dapat dilihat pada Tabel 7.

Tabel 7. Perbandingan titik netral dan friksi negatif metode Fellenius dan Prakash \& Sharma

\begin{tabular}{cccc}
\hline & Potongan & Potongan & Potongan \\
& A-A dan B-B & C-C & D-D \\
\hline Titik netral metode Fellenius (m) & 11,5 & 14 & 27,5 \\
Titik netral metode Prakash \& Sharma (m) & 12 & 15,75 & 22,5 \\
Friksi negatif metode Fellenius (ton) & 29,33 & 37,5 & 42,49 \\
Friksi negatif metode Prakash \& Sharma (ton) & 28,26 & 69,1 & 97,41 \\
\hline
\end{tabular}

Seperti yang dapat dilihat pada Tabel 6., terdapat nilai daya dukung izin yang tidak memenuhi kriteria desain yang diinginkan. Oleh karena itu dilakukan desain ulang agar memenuhi desain minimum. Hasil daya dukung ultimit dan daya dukung izin desain ulang ini dapat dilihat pada Tabel 8.

Tabel 8. Perbandingan daya dukung redesign berbagai metode (ton)

\begin{tabular}{cccccc}
\hline & Undrained & Drained & $\begin{array}{l}\text { Meyerhof } \\
(1956)\end{array}$ & $\begin{array}{l}\text { Meyerhof } \\
(1976)\end{array}$ & Vesic \\
\hline Qult potongan A-A dan B-B & 567,97 & 358,25 & 436,11 & 408,79 & 382,82 \\
Qizin potongan A-A dan B-B & 179,72 & 109,82 & 135,77 & 126,67 & 118,01 \\
Qult potongan C-C & 579,22 & 862,04 & 430,55 & 389,56 & 393,46 \\
Qizin potongan C-C & 175,31 & 269,58 & 118,92 & 118,52 & 104,09 \\
Qult potongan D-D & 453,53 & 669,97 & 465,78 & 427,51 & 427,51 \\
Qizin potongan D-D & 111,46 & 198,04 & 116,36 & 101,05 & 127,85 \\
\hline
\end{tabular}

Berdasarkan Tabel 6. Dan Tabel 8., adanya perubahan nilai daya dukung tiang. Hal ini disertai juga dengan berubahnya ukuran tiang, yaitu diameternya. Perubahan diameter tiang dapat dilihat pada Tabel 9. 
Tabel 9. Perubahan diameter tiang berbagai metode (mm)

\begin{tabular}{|c|c|c|c|c|c|}
\hline & Undrained & Drained & $\begin{array}{c}\text { Meyerhof } \\
(1956)\end{array}$ & $\begin{array}{c}\text { Meyerhof } \\
(1976)\end{array}$ & Vesic \\
\hline D potongan $\mathrm{A}-\mathrm{A}$ dan $\mathrm{B}-\mathrm{B}$ & 500 & 500 & 500 & 500 & 500 \\
\hline $\mathrm{D}$ redesign potongan $\mathrm{A}-\mathrm{A}$ dan $\mathrm{B}-\mathrm{B}$ & 500 & 500 & 500 & 500 & 500 \\
\hline D potongan $\mathrm{C}-\mathrm{C}$ & 300 & 300 & 300 & 300 & 300 \\
\hline $\mathrm{D}$ redesign potongan $\mathrm{C}-\mathrm{C}$ & 300 & 300 & 600 & 450 & 350 \\
\hline D potongan D-D & 200 & 200 & 200 & 200 & 200 \\
\hline $\mathrm{D}$ redesign potongan D-D & 250 & 200 & 700 & 350 & 250 \\
\hline
\end{tabular}

\section{KESIMPULAN DAN SARAN}

\section{Kesimpulan}

Berdasarkan analisis data dan pembahasan yang telah dilakukan, dihasilkan kesimpulan sebagai berikut:

1. Gesekan selimut negatif tidak terjadi pada tanah dimana nilai N-SPT pada ujung tiang besar. Sedangkan semakin kecil nilai N-SPT pada ujung tiang, kemungkinan terjadi gesekan kulit negatif semakin besar.

2. Letak titik netral berdasarkan metode Fellenius dan Prakash \& Sharma antara 0,65-0,95 dari panjang tiang.

3. Besarnya friksi negatif tiang akibat timbunan setinggi dua meter adalah $6-15 \%$ dari daya dukung ultimit tiang.

4. Besarnya daya dukung izin akibat adanya friksi negatif dari timbunan setinggi dua meter adalah 23-32\& dari daya dukung ultimit.

5. Perubahan diameter tiang akibat timbunan setinggi dua meter di daerah Jakarta Utara antar 0-2,5 kali diameter awal berdasarkan analisis dengan berbagai metode.

\section{Saran}

Dari hasil analisis dan perhitungan yang telah dilakukan terhadap tiang pancang, diharapkan dilakukan analisis lain dengan menggunakan metode dan kombinasi rumus yang lebih beragam, serta pengolahan parameter tanah yang lebih akurat dalam mendesain tiang pancang yang tahan terhadap friksi negatif.

\section{DAFTAR PUSTAKA}

Binamarga, Kementrian Pekerjaan Umum dan Perumahan Rakyat Direktorat Jendral. Kumpulan Korelasi Parameter Geoteknik dan Fondasi. Jakarta, 2019.

Das, Braja M. Principal of Foundation Engineering. USA: Cengage Learning, 2014.

Fellenius, Bengt H. Basic of Foundation Design. Canada, 2020.

Rajapakse, Ruwan Abey. Geotechnical Engineering Calculations and Rules of Thumb. New York: Joe Hayton, 2016.

Shamser Prakash, Hari D. Sharma. Pile Foundations in Engineering Practice. Canada: A-Wiley Interscience Publication, 1990.

Badan Standardisasi Nasional. SNI 2847: 2013. Persyaratan Beton Struktural untuk Bangunan Gedung. Bandung: Badan Standarisasi Nasional, 2013.

Suyono Sosrodarsono, Kazuto Nakazawa. Mekanika Tanah dan Teknik Pondasi. Jakarta: PT. Pertja, 2000. 
